\title{
Upper Arm Anthropometry Is Not a Valid Predictor of Regional Body Composition in Preterm Infants
}

\author{
L. Pereira-da-Silva ${ }^{a, b} \quad$ F. Abecasis ${ }^{c} \quad$ D. Virella ${ }^{a} \quad$ J.M. Videira-Amaral ${ }^{b}$ \\ ${ }^{a}$ Neonatal Intensive Care Unit, Hospital de Dona Estefânia, ${ }^{\text {b }}$ Department of Pediatrics, Faculdade de Ciências \\ Médicas, Universidade Nova de Lisboa, and 'Magnetic Resonance Diagnostic Center, Lisbon, Portugal
}

\section{Key Words}

Body composition - Magnetic resonance imaging $\cdot$ Preterm infant $\cdot$ Upper arm anthropometry

\begin{abstract}
Background: Upper arm anthropometry has been used in the nutritional assessment of small infants, but it has not yet been validated as a predictor of regional body composition in this population. Objective: Validation of measured and derived upper arm anthropometry as a predictor of arm fat and fat-free compartments in preterm infants. Methods: Upper arm anthropometry, including the upper arm cross-sectional areas, was compared individually or in combination with other anthropometric measurements, with the cross-sectional arm areas measured by magnetic resonance imaging, in a cohort of consecutive preterm appropriate-for-gestationalage neonates, just before discharge. Results: Thirty infants born with (mean \pm SD) a gestational age of $30.7 \pm 1.9$ weeks and birth weight of 1,380 $\pm 325 \mathrm{~g}$, were assessed at $35.4 \pm$ 1.1 weeks of corrected gestational age, weighing 1,785 \pm $93 \mathrm{~g}$. None of the anthropometric measurements are reliable predictors $\left(r^{2}<0.56\right)$ of the measurements obtained by magnetic resonance imaging, individually or in combination with other anthropometric measurements. Conclusion: Both measured anthropometry and derived upper arm anthropometry are inaccurate predictors of regional body composition in preterm appropriate-for-gestational-age infants.
\end{abstract}

Copyright $\odot 2008$ S. Karger AG, Basel

\section{KARGER}

Fax +41613061234 E-Mail karger@karger.ch www.karger.com

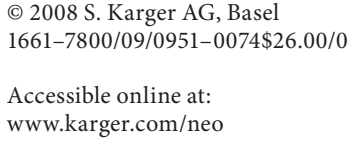

\section{Introduction}

Mid-arm circumference (MAC) and skinfold thickness of the arm have been used as simple, noninvasive and inexpensive tools for the assessment of the nutritional status of neonates [1]. Upper arm cross-sectional areas, derived from MAC and triceps skinfold thickness (TS), has been preferred for the assessment of body composition and nutritional status in small infants [2-5], assuming that it would represent a better indicator of the relative contribution of fat and muscle to the total arm area than TS and MAC by themselves [6, 7]. Theoretical assumptions for the calculation of arm muscle and fat areas are based on the fact that the mid-arm is cylindrical, the subcutaneous fat is a concentric ring evenly distributed around a circular core of muscle, the fat thickness is half the TS, and the muscle includes the humeral diameter [6]. Using the equations proposed by Rolland-Cachera et al. [8], it is also assumed that the arm muscle area constitutes a circle surrounded by a rim (fat), the unrolled rim is a rectangle, and the outer circumference of the rim is equal to the inner circumference. Reference values for upper arm cross-sectional areas have been proposed for fullterm and preterm neonates [9-11].

Using dual X-ray absorptiometry as a reference method, upper arm anthropometry has been recently validated as proxy for regional and total body composition in neonates $[12,13]$. In this age group, the upper arm an-

Prof. Luis Pereira-da-Silva

Neonatal Intensive Care Unit, Hospital Dona Estefânia

Rua Jacinta Marto

PT-1169-045 Lisbon (Portugal)

Tel. +351 21312 6613, Fax +351 21716 7203, E-Mail l.pereira.silva@netcabo.pt 
thropometry shows a good predictive value for total body composition [13], and the TS may give a rough estimate of total body fat [12].

If these were to be consistent, the regional anthropometric measurements capable of predicting total body composition should also be reliable predictors of regional body composition. Upper arm cross-sectional areas measured by anthropometry showed to be good predictors of arm fat and fat-free compartments in adults [14] and children aged 9-15 years [8], using computerized tomography scan or magnetic resonance imaging (MRI) as gold standard methods. In these studies, constants were found to improve the accuracy of anthropometry as predictors of body composition. Validations using gold standard imaging methods of the arm have not yet been performed in neonates. Meanwhile, in several studies the upper arm cross-sectional areas have been used to assess the nutritional status and body composition of small infants [2-5]. However, it is not clear whether the above-mentioned geometrical assumptions used in the calculation of the arm compartments $[6,8]$ are reliable in this age group. Due to the convenience of bedside measurement of upper arm anthropometry in nutritional assessment, there is a need to validate this method in neonates [15].

The MRI method has been validated as a direct, reliable and noninvasive method for measuring the adipose tissue, capable of quantifying even discrete adipose tissue depots [16-19]. Recently, MRI has been used in the assessment of body composition and nutritional status in small infants [20-22].

This study aims to validate measured (MAC and TS) and derived upper arm (cross-sectional arm areas) anthropometry as a predictor of regional body fat and fatfree mass in preterm infants, using MRI as the gold standard for measuring the arm compartments.

\section{Methods}

Consecutive newborn infants with gestational age $\leq 33$ weeks, appropriate for gestational age, were evaluated just before discharge, after obtaining parental consent, and in accordance with the Hospital Ethics Committee. Infants with major congenital malformations, or requiring diuretics or supplemental oxygen at the time of evaluation were excluded.

\section{Anthropometry}

All the anthropometric measurements were performed by the same experienced observer (L.P.d.S.). Body weight (W), length $(\mathrm{L})$, and head circumference ( $\mathrm{HC}$ ) were measured as recommended [23], and MAC and TS were measured as previously described [24]. Indices based on W and L were calculated: the weight-to-

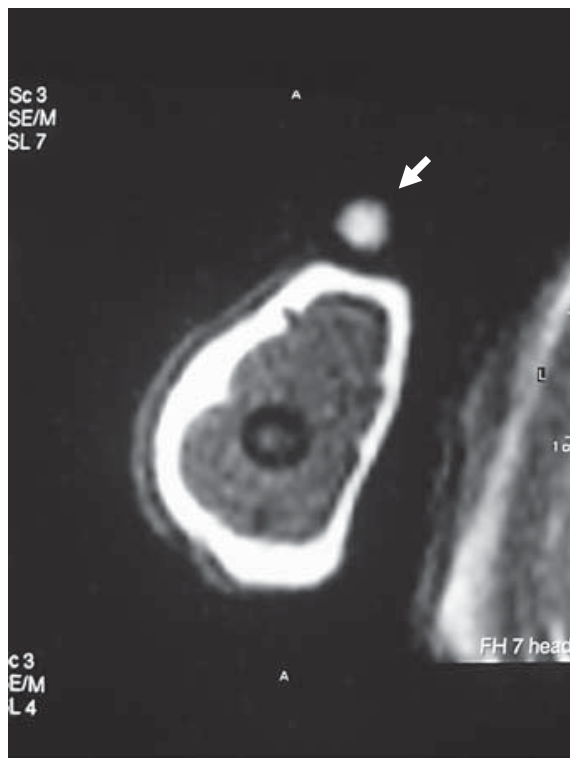

Fig. 1. MR image: the hyper-signal of lecithin beacons the most appropriate transaxial image.

length index $(\mathrm{W} / \mathrm{L})=\mathrm{W}$ (in $\mathrm{g}$ ) $/ \mathrm{L}$ (in $\mathrm{cm}$ ), the adiposity index $(\mathrm{AI})=\mathrm{W}($ in $\mathrm{kg}) / \mathrm{L}^{2}$ (in $\left.\mathrm{m}\right)$, and the ponderal index $(\mathrm{PI})=100 \times$ $\mathrm{W}$ (in $\mathrm{g}$ ) $/ \mathrm{L}^{3}$ (in $\mathrm{cm}$ ). The cross-sectional arm areas, such as total arm area (AA), arm muscle area (AMA), and arm fat area (AFA), were calculated using two alternative methods:

Method of Jelliffe and Jelliffe [6]: $\mathrm{AA}=\mathrm{MAC}^{2} / 4 \pi ; \mathrm{AMA}^{\mathrm{J}}=$ $(\mathrm{MAC}-\pi \mathrm{TS}) / 4 \pi ; \mathrm{AFA}^{\mathrm{J}}=\mathrm{AA}-\mathrm{AMA}^{\mathrm{J}}$.

Method of Rolland-Cachera et al. [8]: $\mathrm{AFA}^{\mathrm{R}}=\mathrm{MAC} \times \mathrm{TS} / 2$; $A M A^{R}=A A-A F A^{R}$.

\section{MRI and Image Analysis}

Magnetic resonance images (AA ${ }^{\mathrm{MRI}}, \mathrm{AFA}^{\mathrm{MRI}}$ and $\mathrm{AMA}^{\mathrm{MRI}}$ ) were acquired on a 1.5-tesla Philips Gyroscan ACS-NT, PowerTrack 1000 scanner. The MRI sequence used in this study was adapted from previously developed scanning protocols involving small infants $[20,21]$ : a rapid $\mathrm{T}_{1}$-weighted spin-echo image sequence, with repetition time $=284 \mathrm{~ms}$, echo time $=18 \mathrm{~ms}$, field of view $=150 \mathrm{~mm}$, number of signal averages $=2$, and a $256 \times 256$ matrix after phase conjugate symmetry. Nine 3-mm-thickness transverse images with $0.3-\mathrm{mm}$ interslice distance were taken during a total acquisition time of $1.58 \mathrm{~min}$.

The infants were positioned supine into a knee coil, and no sedation was used. Considering the $\mathrm{T}_{1}$ hyper-signal of lecithin $[25,26]$, a small capsule of lecithin was fixed on the anterior part of the arm, at the previously marked level where the anthropometric measurements were performed. Care was taken to reduce the deformation of soft tissues. The hyper-signal of lecithin permitted to choose the more appropriate transaxial image at the level of the anthropometric measurements (fig. 1).

The same observer (F.A.) defined the criteria for discriminating the subcutaneous adipose tissue (white appearance) from muscle (gray appearance), and manually traced the circumferences: arm (MAC $\left.{ }^{\mathrm{MRI}}\right)$, muscle (MAMC ${ }^{\mathrm{MRI}}$ ) and bone. The areas 


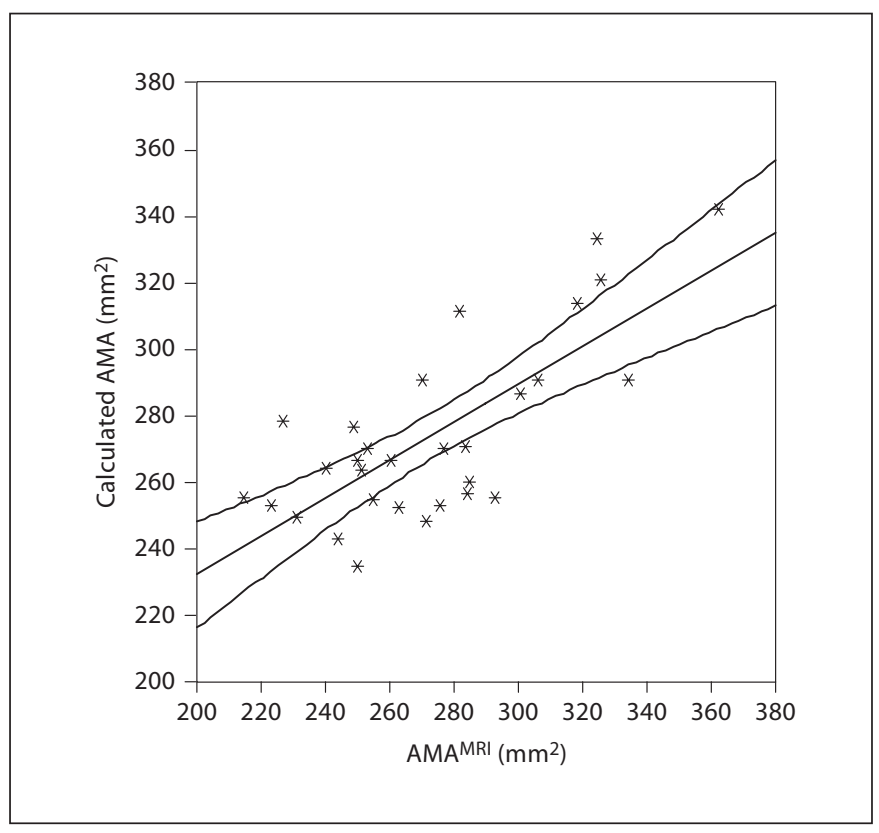

Fig. 2. Validation of the alternative equation for estimation of AMA: $\mathrm{AMA}^{\mathrm{MRI}}=(\mathrm{W} \times 0.17)+(\mathrm{MAC} \times 5.2)-(\mathrm{L} \times 6)-150$; $\mathrm{W}$ expressed in $\mathrm{g}, \mathrm{L}$ in $\mathrm{cm}$, and MAC in $\mathrm{mm}$. Coefficient of determination $r^{2}=0.562$. Regression line with $95 \%$ confidence interval.

included in the circumferences were automatically calculated by pixel counting by the incorporated software.

In pilot measurements, the precision of bone area discrimination was not satisfactory, with an average coefficient of variation (CV) 5.9\% (range 1.2-13.8\%). Therefore, bone was included in $\mathrm{AMA}^{\mathrm{MRI}}$. The average $\mathrm{CV}$ of $\mathrm{AMA}^{\mathrm{MRI}}$ was $1.7 \%$ (range $0.3-4.7 \%$ ). The AFA ${ }^{M R I}$ was obtained by subtracting the AA ${ }^{\mathrm{MRI}}$ from $\mathrm{AMA}^{\mathrm{MRI}}$. The MAC was, therefore, the only direct anthropometric measurement possible to validate by MRI. In the first 20 cases, manual tracing was carried out in triplicate to determine the intraobserver CV. In the last 10 cases, three consecutive acquisitions of images were done to determine the intraobserver $\mathrm{CV}$ for the acquisition of images by the same operator.

\section{Statistical Analysis}

Normal distribution of every variable was verified graphically and through the Kolmogorov-Smirnov test. MRI measurements were correlated individually with each upper arm anthropometry measurement (MAC, TS, and upper arm cross-sectional areas) using the Pearson bivariate correlation test. The predictive value of MRI measurements by each anthropometric measurement and their derived indices was assessed by the coefficients of determination, and was considered as unfit if below 0.5 , mediocre if between 0.5 and 0.75 , acceptable if between 0.76 and 0.85 , good if between 0.86 and 0.95 , and excellent if above 0.95 .

Multiple regression analysis (enter method) was used to find associations of anthropometric measurements (MAC, TS, AMA, AFA, W, L, W/L, AI, PI and HC) that could be transformed into alternative equations to be correlated with MRI measurements.
Table 1. Distribution of the anthropometric measurements

\begin{tabular}{lrrrr}
\hline Measurement & Median & Maximum & Minimum & Mean \pm SD \\
\hline W, g & $1,757.5$ & $1,990.0$ & $1,640.0$ & $1,784.7 \pm 93.3$ \\
L, cm & 43.0 & 45.2 & 41.0 & $43.1 \pm 1.1$ \\
HC, cm & 30.7 & 33.0 & 28.0 & $30.6 \pm 1.1$ \\
MAC, mm & 72.2 & 79.7 & 67.7 & $72.9 \pm 0.7$ \\
TS, mm & 2.5 & 3.1 & 2.0 & $2.5 \pm 0.1$ \\
W/L & 41.0 & 46.1 & 39.1 & $41.4 \pm 1.9$ \\
AI & 9.5 & 10.9 & 8.8 & $9.6 \pm 0.5$ \\
PI & 2.2 & 2.6 & 1.9 & $2.2 \pm 0.2$ \\
AA, mm & 414.5 & 505.1 & 364.4 & $423.7 \pm 8.0$ \\
AMA mm $^{2}$ & 328.6 & 410.9 & 285.7 & $337.7 \pm 6.8$ \\
AMA $^{R}, m^{2}$ & 324.0 & 407.2 & 280.9 & $332.8 \pm 6.8$ \\
AFA $^{\mathrm{J}}, \mathrm{mm}^{2}$ & 87.0 & 111.2 & 66.2 & $86.0 \pm 2.6$ \\
AFA $^{R}, \mathrm{~mm}^{2}$ & 91.8 & 118.2 & 69.4 & $90.9 \pm 2.9$ \\
\hline
\end{tabular}

Table 2. Distribution of the MRI measurements

\begin{tabular}{lrccc}
\hline Measurement & Median & Maximum & Minimum & Mean \pm SD \\
\hline MAC $^{\text {MRI }}$, mm & 78.9 & 92.0 & 70.2 & $79.3 \pm 5.1$ \\
MAMC $^{\text {MRI }}$, mm & 60.8 & 73.1 & 53.8 & $61.1 \pm 3.6$ \\
AA $^{\text {MRI }}$, mm $^{2}$ & 425.6 & 540.0 & 340.5 & $427.9 \pm 6.5$ \\
AMA $^{\text {MRI }}$, mm $^{2}$ & 270.9 & 362.3 & 214.7 & $273.5 \pm 4.7$ \\
AFA $^{\text {MRI }}$, mm $^{2}$ & 149.2 & 227.4 & 96.4 & $154.4 \pm 9.06$ \\
\hline
\end{tabular}

The validity of the equations was assessed by their coefficient of determination.

Statistical analysis was performed with Microsoft Excel $2000^{\mathrm{TM}}$ and SPSS ${ }^{\mathrm{TM}} 6.13$ (SPSS, Inc., Chicago, Ill., USA) statistical packages.

\section{Results}

Thirty infants born with a (mean \pm SD) gestational age of $30.7 \pm 1.9$ weeks and birth weight of 1,380 \pm $325 \mathrm{~g}$ were evaluated at a corrected gestational age of $35.4 \pm 1.1$ weeks, when they weighted $1,786 \pm 93 \mathrm{~g}$.

The intraobserver $\mathrm{CV}$ for the acquisition of images by the operator was $2.0 \%(0.3-4.8)$ for $\mathrm{AMA}^{\mathrm{MRI}}$, and $4.4 \%$ (0.5-11.4) for AFA ${ }^{\mathrm{MRI}}$. The intraobserver $\mathrm{CV}$ for the manual tracing by the observer was $1.6 \%(0.6-2.9)$ for $\mathrm{AMA}^{\mathrm{MRI}}$, and 4.2\% (1.6-12.0) for AFA ${ }^{\mathrm{MRI}}$. No significant differences in MRI measurements between sexes were found. 
Body and arm anthropometry (table 1) and measurements obtained by MRI (table 2) are expressed as mean and standard deviation. The MAC proved to be poor predictor $\left(\mathrm{r}^{2}=0.41\right)$, underestimating the MAC ${ }^{\mathrm{MRI}}$ (fig. 2). None of the individual (table 3) or combined (table 4) anthropometric measurements proved to be an acceptable predictor of the MRI measurements: $\mathrm{r}^{2}<0.45$ and $\mathrm{r}^{2}<$ 0.56 , respectively.

\section{Discussion}

Body weight is commonly used as an isolated measure in the assessment of the nutritional status of small infants in most clinical settings. However, it gives a poor insight into body composition; therefore, weight gain does not necessarily mean growth [27]. The complementary use of some other validated anthropometric measurement predicting regional or total body composition in small infants would represent a useful tool in clinical practice.

Upper arm anthropometry is convenient, particularly in infants that require minimal handling. For this reason, it has been frequently used as a predictor of regional or global body composition in small infants [1-5]. In this population, Schmelzle and Fusch [12] and Koo et al. [13] found a reasonable correlation between the skinfold measurements, including TS, and the total body fat. Others have reported a poor correlation between skinfold measurements and total body fat in newborn infants $[22,27]$. This may be due to several factors, including the influence of hydration on the skinfold compressibility [22], and the possibility that skinfold measurements may not reflect nonsubcutaneous fat [21]. In small infants, an unsatisfactory correlation has been described between MAC measurements and body fat and fat-free mass [28], but others have found that MAC measurements may have a reasonable predictive value [13]. Taking into account the contradictory predictive values of TS and MAC found in small infants, validation of upper arm cross-sectional areas assumes special relevance in this population, since their calculation relies on TS and MAC measurements.

Compared with ultrasound measurements, upper arm cross-sectional areas derived by anthropometry may lead to overestimation of muscle and underestimation of fat in full-term neonates [24]. In this population, Kabir and Forsum [29] also found that TS underestimates the adipose tissue in comparison with ultrasound measurements. Like anthropometry, the ultrasonic method has shortcomings when measuring subcutaneous tissue [30] and cross-sectional muscle areas, at least in adults [31].
Table 3. Coefficient of determination $\left(\mathrm{r}^{2}\right)$ of the individual anthropometric measurements

\begin{tabular}{llll}
\hline Anthropometry & \multicolumn{2}{l}{ MRI } & \\
\cline { 2 - 4 } & $\begin{array}{l}\mathrm{AA}^{\mathrm{MRI}} \\
(427.9 \pm 6.5 \\
\left.\mathrm{mm}^{2}\right)\end{array}$ & $\begin{array}{l}\mathrm{AMA}^{\mathrm{MRI}} \\
(273.5 \pm 4.7 \\
\left.\mathrm{mm}^{2}\right)\end{array}$ & $\begin{array}{l}\mathrm{AFA}^{\mathrm{MRI}} \\
(154.4 \pm 9.1 \\
\left.\mathrm{mm}^{2}\right)\end{array}$ \\
\hline W $(1,784.6 \pm 93.3 \mathrm{~g})$ & - & 0.372 & 0.024 \\
$\mathrm{~L}(47.1 \pm 1.1 \mathrm{~cm})$ & - & 0.032 & 0.020 \\
$\mathrm{HC}(30.6 \pm 1.1 \mathrm{~cm})$ & - & 0.012 & 0.020 \\
MAC $(72.9 \pm 0.7 \mathrm{~mm})$ & - & 0.449 & 0.048 \\
TS $(2.5 \pm 0.1 \mathrm{~mm})$ & - & - & 0.058 \\
W/L $(41.4 \pm 1.9)$ & - & - & 0.010 \\
AI $(1.0 \pm 0.05)$ & - & - & 0.000 \\
PI $(2.2 \pm 0.2)$ & - & - & 0.001 \\
AA $\left.(423.7 \pm 8.0 \mathrm{~mm})^{2}\right)$ & 0.422 & 0.449 & 0.048 \\
AFA $^{\mathrm{J}}\left(86.0 \pm 2.6 \mathrm{~mm}^{2}\right)$ & - & - & 0.410 \\
AFA $^{\mathrm{R}}\left(90.9 \pm 2.9 \mathrm{~mm}^{2}\right)$ & - & - & 0.397 \\
AMA $^{\mathrm{J}}\left(337.7 \pm 6.8 \mathrm{~mm}^{2}\right)$ & - & 0.073 & - \\
AMA $^{\mathrm{R}}\left(332.8 \pm 6.7 \mathrm{~mm}^{2}\right)$ & - & 0.073 & - \\
\hline
\end{tabular}

Table 4. Coefficient of determination $\left(\mathrm{r}^{2}\right)$ of the combined anthropometric measurements, including anthropometric indexes

\begin{tabular}{|c|c|c|}
\hline \multirow[t]{2}{*}{ Anthropometry } & \multicolumn{2}{|l|}{ MRI } \\
\hline & $\mathrm{AMA}^{\mathrm{MRI}}$ & $\mathrm{AFA}^{\mathrm{MRI}}$ \\
\hline MAC and L & 0.449 & - \\
\hline MAC and $\mathrm{W}$ & 0.533 & 0.053 \\
\hline MAC, $\mathrm{W}$ and $\mathrm{L}$ & 0.562 & - \\
\hline MAC, W, L and HC & 0.562 & - \\
\hline TS and W & - & 0.068 \\
\hline TS, $\mathrm{W}$ and $\mathrm{HC}$ & - & 0.068 \\
\hline $\mathrm{AMA}^{\mathrm{J}}$ and $\mathrm{L}$ & 0.410 & - \\
\hline $\mathrm{AMA}^{\mathrm{J}}$ and $\mathrm{W}$ & 0.518 & - \\
\hline $\mathrm{AMA}^{\mathrm{J}}, \mathrm{W}$ and $\mathrm{L}$ & 0.548 & - \\
\hline $\mathrm{AMA}^{\mathrm{J}}, \mathrm{W}, \mathrm{L}$ and $\mathrm{HC}$ & 0.548 & - \\
\hline $\mathrm{AMA}^{\mathrm{R}}$ and $\mathrm{L}$ & 0.410 & - \\
\hline $\mathrm{AMA}^{\mathrm{R}}$ and $\mathrm{W}$ & 0.504 & - \\
\hline $\mathrm{AMA}^{\mathrm{R}}, \mathrm{W}$ and $\mathrm{L}$ & 0.548 & - \\
\hline $\mathrm{AMA}^{\mathrm{R}}, \mathrm{W}, \mathrm{L}$ and $\mathrm{HC}$ & 0.548 & - \\
\hline $\mathrm{AFA}^{\mathrm{J}}$ and $\mathrm{W}$ & - & 0.078 \\
\hline $\mathrm{AFA}^{\mathrm{J}}, \mathrm{W}$ and $\mathrm{HC}$ & - & 0.116 \\
\hline $\mathrm{AFA}^{\mathrm{R}}$ and $\mathrm{W}$ & - & 0.078 \\
\hline $\mathrm{AFA}^{\mathrm{R}}, \mathrm{W}$ and $\mathrm{HC}$ & - & 0.116 \\
\hline $\mathrm{AFA}^{\mathrm{J}}$ and $\mathrm{W} / \mathrm{L}$ & - & 0.075 \\
\hline $\mathrm{AFA}^{\mathrm{J}}$ and $\mathrm{AI}$ & - & 0.078 \\
\hline $\mathrm{AFA}^{\mathrm{J}}$ and PI & - & 0.081 \\
\hline $\mathrm{AFA}^{\mathrm{R}}$ and $\mathrm{W} / \mathrm{L}$ & - & 0.074 \\
\hline $\mathrm{AFA}^{\mathrm{R}}$ and $\mathrm{AI}$ & - & 0.077 \\
\hline $\mathrm{AFA}^{\mathrm{R}}$ and $\mathrm{PI}$ & - & 0.081 \\
\hline
\end{tabular}


In this study, the MRI was chosen as the gold standard method for measuring the arm compartments. This direct and noninvasive method has been validated in animals [17], human cadavers [18], and human adults [19] for the assessment of adipose tissue. It has also been used in lean tissue assessment in human beings, although with lower precision [32]. The excellent precision in identifying the adipose tissue [16] has been important for distinguishing subcutaneous adipose tissue from muscle, permitting a more reliable manual tracing of the arm circumference and the inner limit of the subcutaneous fat ring separating subcutaneous adipose tissue from muscle (muscle circumference). Considering the poor precision of bone MRI measurements in this study, bone was included in $\mathrm{AMA}^{\mathrm{MRI}}$, comparing reasonably well to anthropometric AMA, which also includes bone area.

The MRI measurements were correlated with upper arm anthropometric measurements both individually and in combination with other anthropometric measurements. Among the individual measurements, MAC had a surprisingly poor predictive value. In very premature infants, this may be explained by the difficulty in adjusting perfectly the tape around their arms with very soft tissues, leading to a significant compression of the skin. To avoid compression, small spaces may be left between the wrinkled skin. By contrast, the MAC measured by MRI is not affected by compression, and its reliability is mainly dependent on the observer's manual tracing.

The rationale for combining anthropometric measurements was to join on the same equation several anthropometric measurements that might reflect the same body compartments, a methodology used by others [13]. For instance, L was combined with AMA derived by anthropometry when correlated with AMA ${ }^{\mathrm{MRI}}$, since L is considered a global indicator of lean body mass [33]; indices based on the $\mathrm{W}$ and the L, such as PI [21], AI [34] and W/L [35] may roughly reflect the adiposity. Both ap- proaches failed to find any acceptable predictor of the upper arm compartments.

The present results are not fully consistent with the results of Schmelzle and Fusch [12] and Koo et al. [13], probably due to some methodological differences. Both studies $[12,13]$ evaluated the predictive value of regional and whole body anthropometry for total body composition using dual X-ray absorptiometry as the gold standard, while we considered MRI as more adequate for morphological measurements and estimation of regional body composition. The evaluation of upper arm anthropometry as predictor of whole-body composition was beyond the scope of our study. Both studies $[12,13]$ analyzed mixed samples of full-term and preterm neonates, including appropriate for gestational age, large and small for gestational age neonates, assessed during the first days of life; the patients in the study of Schmelzle and Fusch [12] were also assessed at 2 and 4 months of age. Our study focused only on appropriate-for-gestationalage preterm babies, assessed at discharge.

Our results confirm that both measured anthropometry and derived upper arm anthropometry, either isolated or in combination with the other anthropometric measurements, are inaccurate predictors of regional body composition in appropriate-for-gestational-age preterm infants. This raises concerns about the validity of previous studies in this population assessing the body composition and nutritional status based on upper arm anthropometry; therefore, the results of these studies should be interpreted with caution.

\section{Acknowledgment}

The authors are very grateful to the Luso-American Development Foundation for supporting the present study (project 77/99).

\section{References}

1 Excler JL, Sann L, Lasne Y, Picard J: Anthropometric assessment of nutritional status in newborn infants: discriminative value of mid-arm circumference and skinfold thickness. Early Hum Dev 1985;11:169-178.

2 GeorgieffMK, Mills MM, ZempelCE, Chang P-N: Catch-up growth, muscle and fat accretion, and body proportionality of infants one year after newborn intensive care. J Pediatr 1989;114:288-292.

\footnotetext{
- 3 deRegnier RA, Guilbert TW, Mills MM, Georgieff MK: Growth failure and altered body composition are established by one month of age in infants with bronchopulmonary dysplasia. J Nutr 1996;126:168-175.

-4 Hediger ML, Overpeck MD, Kucsmarski RJ, McGlynn A, Maurer KR, Davis WW: Muscularity and fatness of infants and young children born small- or large-for-gestational age. Pediatrics 1998;102:E60.
}

5 Sun M, Schutz Y, Grezzani A, Clementi M, Gaudino R, Maffeis C: Body size and early growth in appropriate- and large-for-gestational-age infants. Acta Paediatr 2003;92: $1127-1132$.

6 Jelliffe EFP, Jelliffe DB: The arm circumference as a public health index of protein-calorie malnutrition of early childhood. J Trop Pediatr 1969;32:1527-1530. 
7 Frisancho AR: New norms of upper limb fat and muscle areas for assessment of nutritional status. Am J Clin Nutr 1981;34:25402545.

$>8$ Rolland-Cachera MF, Brambilla P, Manzoni P, Akrout M, Sironi S, Del Maschio A, et al: Body composition assessed on the basis of arm circumference and triceps skinfold thickness: a new index validated in children by magnetic resonance imaging. Am J Clin Nutr 1997;65:1709-1713.

-9 Sann L, Durand M, Picard J, Lasne Y, Bethenod M: Arm fat and muscle areas in infancy. Arch Dis Child 1988;63:256-260.

-10 Amit Y, Jabbour S, Arad ID: Standards of skinfold thickness and anthropometric indices in term Israeli newborn infants. Isr J Med Sci 1993;29:632-635.

-11 Fleta Zaragozano J, Lario Munoz A, Lario Elboj A, Ventura Faci P, Samper Villagrasa MP, Bueno Sanchez M, et al: Brachial measurements as nutritional indicators in health term newborns. An Esp Pediatr 1999;51: 525-529.

>12 Schmelzle HR, Fusch C: Body fat in neonates and young infants: validation of skinfold thickness versus dual-energy X-ray absorptiometry. Am J Clin Nutr 2002;76:10961100.

$\checkmark 13$ Koo WW, Walters JC, Hockman EM: Body composition in neonates: relationship between measured and derived anthropometry with dual-energy X-ray absorptiometry measurements. Pediatr Res 2004;56:694700.

14 Heymsfield SB, McManus C, Smith J, Stevens V, Nixon DW: Anthropometric measurement of muscle mass: revised equations for calculating bone-free arm muscle area. Am J Clin Nutr 1982;36:680-690.

15 Pereira-da-Silva L, Virella D, Videira-Amaral JM: The need to validate arm measurements in newborn infants. An Esp Pediatr 2000;53:387.
16 Harrington TA, Thomas EL, Modi N, Frost G, Coutts GA, Bell JD: Fast and reproducible method for the direct quantitation of adipose tissue in newborn infants. Lipids 2002. 37:95-100.

17 Ross R, Leger L, Guardo R, De Guise J, Pike BG: Adipose tissue volume measured by magnetic resonance imaging and computerized tomography in rats. J Appl Physiol 1991; 70:2164-2172.

-18 Abate N, Burns D, Peshock RM, Garg A, Grundy SM: Estimation of adipose tissue mass by magnetic resonance imaging: validation against dissection in human cadavers. J Lipid Res 1994;35:1490-1496.

19 Fowler PA, Fuller MF, Glasbey CA, Foster MA, Cameron GG, McNeill G, et al: Total and subcutaneous adipose tissue in women the measurement of distribution and accurate prediction of quantity by using magnetic resonance imaging. Am J Clin Nutr 1991; 54:18-25.

20 Olhager E, Flinke E, Hannerstad U, Forsum E: Studies on human body composition during the first 4 months of life using magnetic resonance imaging and isotope dilution. $\mathrm{Pe}$ diatr Res 2003;54:906-912.

21 Uthaya S, Bell J, Modi N: Adipose tissue magnetic resonance imaging in the newborn. Horm Res 2004;62(suppl 3):143-148.

22 Olhager E, Forsum E: Assessment of total body fat using the skinfold technique in fullterm and preterm infants. Acta Paediatr 2006;95:21-28.

23 Gordon CC, Chumlea WC, Roche AF: Stature, recumbent length and weight; in Lohman TG, Roche AF, Martorell R (eds): Anthropometric Standardization Reference Manual. Champain, Human Kinetic Books, 1988, pp 3-8.

24 Pereira-da-Silva L, Veiga Gomes J, Clington A, Videira-Amaral JM, Bustamante SA: Upper-arm measurements of healthy neonates comparing ultrasonography and anthropometric methods. Early Hum Dev 1999;54: $117-128$

-25 Grant CW, Barber KR, Florio E, Karlik S: A phospholipid spin label used as a liposomeassociated MRI contrast agent. Magn Reson Med 1987;5:371-376.
26 Fenton BW, Lin CS, Seydel F, Macedonia C: Lecithin can be detected by volume-selected proton MR spectroscopy using a $1.5 \mathrm{~T}$ whole body scanner: a potentially non-invasive method for the prenatal assessment of fetal lung maturity. Prenat Diagn 1998;18:12631266.

27 Lapillonne A, Salle BL: Methods for measuring body composition in newborns - a comparative analysis. J Pediatr Endocrinol Metab 1999; 12:125-137.

28 Cross JH, Holden C, MacDonald A, Pearmain G, Stevens MCG, Booth IW: Clinical examination compared with anthropometry in evaluating nutritional status. Arch Dis Child 1995;72:60-61.

29 Kabir N, Forsum E: Estimation of total body fat and subcutaneous adipose in full-term infants less than 3 months old. Pediatr Res 1993;34:448-454.

>30 Borkan GA, Hults DE, Cardarelli, Burrows BA: Comparison of ultrasound and skinfold measurements in assessment of subcutaneous and total fatness. Am J Phys Anthropol 1982;58:307.

-31 Dierking JK, Bemben MG, Bemben DA, Anderson MA: Validity of diagnostic ultrasound as a measure of delayed onset muscle soreness. J Orthop Sports Phys Ther 2000; 30:116-122.

32 Ross R, Rissanen J: Sex differences in lean and adipose tissue distribution by magnetic resonance imaging: anthropometric relationships. Am J Clin Nutr 1994;59:12771285.

33 Koo WW, Walters JC, Hockman EM: Body composition in human infants at birth and postnatally. J Nutr 2000;130:2188-2194.

>34 de Gamarra ME, Schutz Y, Catzeflis C, Freymond D, Cauderay M, Calame A, et al: Skinfold thickness and adiposity index in premature infants. Biol Neonate 1987;51:144-148.

$>35$ Yau KI, Chang MH: Weight to length ratio - good parameter for determining nutritional status in preterm and full-term newborns. Acta Paediatr 1993;82:427-429. 